\title{
Kondisi Psikologis Narapidana Narkotika Di Lembaga Permasyarakatan Narkotika Klas II Karang Intan Martapura, Kalimantan Selatan
}

\author{
Yulia Hairina dan Shanty Komalasari ${ }^{1}$ \\ Jurusan Psikologi Islam Fakultas Ushuluddin dan Humaniora \\ Universitas Islam Negeri (UIN) Antasari Banjarmasin
}

\begin{abstract}
This study aims to describe the psychological condition of inmates during being in Narcotics Correctional Institution II Karang Intan, Martapura, South Kalimantan. The research method used is qualitative research. Method of taking data by using interview and observation. The main research subjects were two prisoners, HRS and BSR were supported by two informants, prison officers and counselors as a complementary source of data. From the results of research can be described psychological condition of inmates are divided into four aspects, namely cognitive aspects, affective aspects, social aspects and psychomotor aspects (behavior). The research findings can be summarized as follows, on the cognitive aspect can be described prisoners are susceptible to cognitive dysfunction this is related to the ability his perception, the ability to catch and often lose concentration, while the affective aspects of deep sadness, suspicion and excessive alertness, And anxious, to social aspects show behavior tend to withdraw from association among fellow inmates, often sat pensive and become loners or close themselves. In the psychomotor aspect can be seen from maladaptive behavior, can manisfestation in the form of behavior of sleeplessness, lack of spirit and loss of interest, even the desire to hurt until the desire to end life.
\end{abstract}

Kata Kunci: Kondisi Psikologis; Narapidana Narkotika; Lembaga Permasyarakatan

\section{Pendahuluan}

Masalah penyalahgunaan narkotika saat ini semakin meluas dan telah menjadi keprihatinan bangsa, banyak nilai kemanusiaan yang dihancurkan narkotika. Narkotika merupakan bahan atau zat yang bila masuk ke dalam tubuh akan mempengaruhi tubuh terutama susunan syaraf pusat atau otak sehingga jika disalahgunakan akan menyebabkan gangguan fisik, psikis/ jiwa dan fungsi sosial. ${ }^{2}$ Dari laporan perkembangan situasi narkotika

\footnotetext{
${ }^{1}$ Korespondensi untuk tulisan ini ditujukan kepada penulis pertama email yhairina@gmail.com

${ }^{2}$ Arsyah Sumardi, Jenis-Jenis Narkoba (Jakarta: Citizen Reporter, 2013). 21.
} 
dunia tahun 2014, diketahui angka estimasi pengguna narkoba di tahun 2012 adalah antara 162 juta hingga 324 juta orang atau sekitar 3,5\%-7\%. ${ }^{3}$

Di Indonesia narkotika menjadi salah satu masalah yang saat ini masih menjadi perhatian pemerintah. Jumlah pengguna narkotika terus mengalami peningkatan dari waktu ke waktu. Menurut data penelitian Badan Narkotika Nasional (BNN) memperkirakan jumlah pengguna narkotika di Indonesia akan terus meningkat. Berdasarkan data BNN di tahun 2015, kenaikan persentase pengguna narkoba di Indonesia mencapai 40\%. Penyalahgunaan narkotika dan bahan adiktif di Indonesia merupakan masalah yang sangat mengkhawatirkan, periode Juni hingga November 2015 sebesar 1,7 juta jiwa. Di bulan Juni 2015 angka pengguna sebesar 4.2 juta dan di bulan November 2015 sebesar 5,9 juta. ${ }^{4}$ Karena posisi Indonesia sekarang ini tidak hanya sebagai daerah transit maupun pemasaran narkotika, psikotropika dan zat adiktif, melainkan sudah menjadi daerah produsen narkotika, psikotropika dan zat adiktif . Di Provinsi Kalimantan Selatan sendiri berdasarkan data yang disampaikan oleh Kepala BNNP Kalimantan Selatan sampai dengan akhir 2016 jumlah pemakai narkotika telah mencapai angka 55.000 orang. ${ }^{5}$

Penanggulangan kejahatan yang berhubungan dengan narkotika sudah dilakukan oleh berbagai pihak dengan banyak cara. Salah satu cara penanggulangannya adalah memberikan sistem pembinaan yang dilakukan di dalam lembaga pemasyarakatan. Kehidupan narapidana di lembaga permasyarakatan merupakan bentuk konsekuensi dari perilakunya, berbagai permasalahan dialami narapidana dalam menjalani kehidupannya di lembaga permasyarakatan, tidak terkecuali narapidana kasus narkotika. Narapidana kasus narkotika adalah seseorang yang dijatuhi hukuman pidana oleh pengadilan disebabkan karena menyalahgunakan narkotika, sehingga harus dipisahkan dari lingkungannya dalam kurun waktu tertentu dan akan kembali ke lingkungannya setelah masa pidana selesai.

Perubahan hidup, hilangnya kebebasan dan hak-hak yang semakin terbatas serta kehidupan yang membuat mereka harus terpisah dari keluarga dan hidup bersama

\footnotetext{
3 UNODC, “World Drug Report 2012," 2012, http://unodc.gov/word-drugs-repoort-2012. Diakses pada tanggal 10 April 2017

4 "Data BNN menunjukkan peningkatan besar pengguna narkoba pasca eksekusi mati pengedar," 2016, http://www.batok.co/2016/04/19/data-bnn-menunjukkan-peningkatan-besar-pengguna-narkoba-pascaeksekusi-mati-pengedar. Di akses pada tanggal 20 April 2017

5 "Jumlah Pengguna Narkoba-di Kalimantan," 2016, http://portalindonesianews.com/posts/view/1626/tahun_2015_jumlah_penggunanarkoba_di_indonesia_capa i_5_juta_orang\#sthas.1sbBk1JA.dpuf. Di akses pada tanggal 20 April 2017
} 
narapidana lain, hal ini tentunya akan memicu timbulnya stres. Hasil penelitian yang dilakukan oleh Holmes dan Rahe menguatkan bahwa kehidupan di dalam lembaga permasyarakatan atau rumah tahanan memang tidak mudah dan terdapat berbagai permasalahan. ${ }^{6}$ Terbukti hukuman penjara menempati urutan keempat dalam skala urutan pengalaman hidup yang menimbulkan stres. Bahkan menurut Cohen dan Taylor menyebut kehidupan di dalam lembaga permasyarakatan atau penjara sebagai keruntuhan hidup menyeluruh (massive life disruption). ${ }^{7}$

Maka, dengan kondisi demikian, sangat memungkinkan seseorang narapidana mengalami tekanan batin, mengembangkan perasaan negatif, dan cara berpikir negatif pula. Bahkan semakin lama mereka mengalami kondisi demikian akan sangat potensial timbulnya gangguan-ganguan psikologis, seperti kecemasan dan depresi ringan sampai berat bahkan bisa menyebabkan bunuh diri karena putus asa, seperti yang terjadi baru-baru ini di sebuah lembaga permasyarakatan kelas 1 di Lowokwaru. ${ }^{8}$

Kondisi yang sama juga dialami sebagian besar narapidana narkotika yang berada di Lembaga Pemasyarakatan Narkotika Klas IIA Karang Intan, Kabupaten Banjar, di Provinsi Kalimantan Selatan. Berdasarkan hasil wawancara kepada seorang petugas Lapas mengemukakan bahwasanya kejadian-kejadian pada narapidana di Lembaga Permasyarakatan Karang Intan yang melukai diri sendiri atau dengan kata lain melakukan percobaan bunuh diri tidak satu dua kali terjadi, selain itu narapidana yang dibawa ke rumah sakit untuk berobat terkait dengan kondisi psikisnya yang sudah tergolong terganggu juga tergolong banyak. Lebih lanjut lagi, dari hasil wawancara dengan salah satu narapidana kasus narkotika, permasalahan yang dirasakan selama berada di lembaga permasyarakatan adalah perasaan bosan, jenuh dengan rutinitas yang ada, dan tidak jarang mereka merasa putus asa dengan keadaan mereka dan merasa tidak memiliki masa depan atau merasa pesimis.

\footnotetext{
${ }^{6}$ Liwarti, "Hubungan antara pengalaman spritual dengan psychological Well-Being pada penghuni LembagaPermasyarakatan," Jurnal Sains dan Praktik Psikologi 1 (2013): 77-88.

${ }^{7}$ Bonar Hutapea, "Terpenjara dan Bahagia? Psychological Well-Being Pada narapidana Ditinjau dari Karakteristik Kepribadian," Kepribadian.Proceeding Pesat (Psikologi, Ekonomi, Sastra, Arsitektur dan Sipil, 2011, 1858-2559.

8 Deny Rahmawan, “Banyak Napi Narkoba Stres,” 2016, http://malangvoice.com/banyak-napi-narkoba-stres/. Diakses ada tanggal 21 April 2017
} 
Menjadi narapidana adalah stresor kehidupan yang berat bagi pelakunya. Perasaan sedih pada narapidana setelah menerima hukuman serta berbagai hal lainnya seperti rasa bersalah, hilangnya kebebasan, perasaan malu, sangsi ekonomi dan sosial serta kehidupan dalam penjara yang penuh dengan tekanan psikologis dapat memperburuk dan mengintensifkan stresor sebelumnya. Keadaan tersebut bukan saja mempengaruhi penyesuaian fisik tetapi juga psikologis individu. ${ }^{9}$

Berdasarkan hal tersebut, peneliti tertarik melakukan penelitian mengenai kondisi psikologis yang dialami narapidana kasus narkotika di Lembaga Permasyarakatan Narkotika Klas II Karang Intan, Martapura, Kalimantan Selatan.

\section{Landasan Teori}

\section{Kondisi Psikologis}

Secara umum kondisi psikologis merupakan keadaan, situasi yang bersifat kejiwaan. Kondisi psikologis juga diuraikan sebagai suatu keadaan yang ada dalam diri seorang individu yang dapat mempengaruhi sikap dan perilaku individu tersebut. Kondisi psikologis dapat diartikan sebagai suatu keadaan psikis yang tidak tampak oleh mata dan mendasari seseorang untuk berperilaku secara sadar. Kondisi psikologis ini merupakan landasan kepribadian seorang individu. ${ }^{10}$ Artinya kepribadian seorang individu bisa tercermin dari bagaimana kondisi psikologisnya dan melibatkan berbagai aspek yaitu cara berpikir atau aspek yang mencakup kegiatan mental/ otak (kognitif), perasaan yang menyangkut aspek emosional (afektif), perilaku (psikomotor), dan sosial yang mana aspekaspek itu saling berinteraksi dan bersifat dinamis.

\section{Narapidana Narkotika}

Narapidana adalah terpidana yang menjalani hukuman kehilangan kemerdekaan di Lembaga Pemasyarakatan sesuai UU No. 12 tahun 1995. Seseorang yang menjadi narapidana adalah dia yang melakukan perbuatan yang dinyatakan terlarang oleh undang-

\footnotetext{
${ }^{9}$ C Morgan, "Developing Mental Health Service for Local Jails," Criminal Psychology: Science and Practice 5 (1981): 291-313.

${ }^{10}$ R. Y Afrinisna, "Penyebab dan kondisi psikologis narapidana kasus narkoba pada remaja” (Universitas Ahmad Dahlan, 2013).
} 
undang di negara Indonesia dan ditentukan oleh proses hukum harus ditempatkan di dalam Lembaga Pemasyarakan sehingga hilang kemerdekaannya. ${ }^{11}$

Adapun munculnya perilaku melanggar hukum dapat disebabkan karena narapidana memiliki kepribadian yang terdistorsi mengandung konflik secara terus menerus, yang salah satu penyebabnya adalah adanya ketidakharmonisan faktor sosiokultural dan psikologis. ${ }^{12}$ Narapidana kasus narkoba berarti seseorang yang dijatuhi hukuman pidana oleh pengadilan disebabkan karena menyalahgunakan narkoba, sehingga harus dipisahkan dari lingkungannya dalam kurun waktu tertentu dan akan kembali ke lingkungannya setelah masa pidana selesai.

Menurut Kristianingsih narapidana narkotika merupakan bagian dari narapidana dengan kondisi yang berbeda dan spesifik, yaitu mempunyai karakter atau perilaku yang cenderung berbeda akibat penggunaan narkoba yang dikonsumsi mereka selama ini, seperti kurangnya tingkat kesadaran akibat rendahnya kemampuan penyerapan, keterpurukan kesehatan dan sifat over reaktif dan over produktif. Akibatnya narapidana kasus narkotika perlu penanganan khusus daripada narapidana kasus lain selama berada di lapas ataupun rutan. ${ }^{13}$

\section{Metode}

\section{Jenis dan Pendekatan Penelitian}

Jenis penelitian yang digunakan dalam penelitian ini adalah penelitian lapangan dengan pendekatan kualitatif-deskriptif yaitu akan memberikan gambaran kondisi psikologis yang meliputi aspek kognitif, afektif, sosial dan psikomotor.

\section{Partisipan Penelitian}

Partisipan yang dijadikan subyek penelitian ini adalah dua orang narapidana, yang berinisial HRS dan BSR, keduanya adalah tahanan dengan kasus yang sama pengedar sekaligus pengguna, masa tahanan kedua subyek di atas lima tahun, keduanya kerap sering

\footnotetext{
${ }^{11}$ Purnianti dan UNICEF, Analisa Situasi Sistem Peradilan Pidana Anak (Juvenile Justice System) di Indonesia (Jakarta: UNICEF, 2003).

${ }^{12}$ Indiyah, "Hubungan antara religiusitas dan kepercayaan diri dengan kecemasan pada narapidana menjelang masa bebas" (Universitas Gadjah Mada, 1997).

${ }^{13}$ S.A Kristianingsih, "Pemaknaan Pemenjaraan pada Narapidana Narkoba di Rumah Tahanan Salatiga," Humanitas Vol 6, no. No. 1 (2009): 1-15.
} 
berada di dalam klinik LP karena kondisi fisik dan psikis yang dikeluhkan, ditambah dengan dua orang informan untuk mencapai kredibilitas penelitian yaitu petugas lapas, dan konselor/ psikolog.

\section{Metode Pengumpulan Data}

Metode pengumpul data yang digunakan adalah wawancara dan observasi. Teknik wawancara yang digunakan adalah wawancara semi terstruktur, sedangkan observasi yang digunakan adalah observasi nonpartisipan. Peneliti dalam penelitian ini hanya mengamati beberapa aktivitas responden dan tidak ikut terjun langsung dalam kehidupannya selama di penjara.

\section{Analisis Data}

Untuk menganalisis data yang telah dikumpulkan oleh peneliti dilakukan proses Induksi-Interprestasi-Konseptualisasi yaitu dengan membuat laporan lapangan yang dari data-data (Induksi), menemukan pikiran yang tersembunyi di balik cerita responden dari hasil wawancara (Interpretasi), dan akhirnya dapat diciptakan suatu konsep (konseptulisasi).

\section{Hasil dan Diskusi}

Berdasarkan data yang telah diperoleh peneliti melalui wawancara dan observasi dapat diketahui bahwasanya menjadi narapidana adalah stresor kehidupan yang berat bagi kedua subyek (HRS dan BSR), belum lagi menjalani keseharian di sebuah lembaga permasyarakatan yang tentunya mengalami keadaan yang jauh berbeda dengan kehidupan di masyarakat pada umumnya. Keadaan tersebut bukan saja mempengaruhi penyesuaian fisik tetapi juga pada aspek psikologis mereka. Dalam penyajian data peneliti membagi kondisi psikologis narapidana ke beberapa aspek yaitu aspek kognitif (pola pikir, daya tangkap), afektif (emosi, perasaan), sosial (hubungan interpersonal dengan oranglain) dan psikomotor (tingkahlaku), agar lebih mudah dipahami.

Dari sisi kognitif dapat di gambarkan narapidana di lembaga permasyarakatan rentan mengalami disfungsi kognitif atau dengan kata lain gangguan fungsi kognitifnya hal ini 
berkaitan dengan kemampuan persepsinya, yaitu daya tangkap mereka terhadap hal-hal yang diterimanya seringkali berbeda dengan apa yang dimaksudkan oleh si pengirim pesan sehingga terjadi kesalahan dalam proses persepsi. Hal ini juga mempengaruhi perilaku dan respon emosinya. Seperti yang disampaikan oleh informan melalui petikan wawamcara di bawah ini:

"Daya tangkap mereka memang agak kurang, selain itu mereka seringkali salah persepsi terhadap apa yang disampaikan baik oleh petugas maupun keluarga yang berkunjung dan pada akhirnya persepsi yang salah itu mengganggu pikirannya, misalnya ketika ada keluarga atau teman yang berkunjung menceritakan tentang istri mereka yang sering ngobrol dengan orang lain, maka pikiran mereka menyimpulkan bahwa istri mereka selingkuh" (wawancara dengan petugas lapas)

Tentunya kemampuan kognitif mereka sedikit banyaknya juga karena masih ada dampak dari zat narkoba yang pernah dikonsumsi narapidana dalam jangka waktu tertentu dan pada akhirnya memberikan pengaruh terhadap kemampuan menerima informasi atau daya konsentrasinya. Intinya kondisi psikologis narapidana yang sekarang mereka alami juga disebabkan oleh narkotika yang pernah mereka konsumsi. Hal ini semakin diperkuat oleh pendapat Sarwono yang mengatakan pemakaian zat narkoba secara berulang akan mengganggu sinyal penghantar syaraf yang disebut sistem neurotransmitter di dalam susunan syaraf sentral, sehingga menyebabkan terganggunya fungsi kognitif. ${ }^{14}$

Selain terganggu fungsi kognitif, subjek baik HRS dan BSR juga mengalami gangguan afektif, misalnya kewaspadaan atau rasa curiga yang meningkat, bahkan sampai terjadi halusinasi penglihatan dan pendengaran, dan tingkah laku maladaptif lainnya. Dari hasil wawancara kepada subjek HRS, ia mengatakan bahwa ia selama di LP sering mendengar bisikan seperti dikatakannya adalah hati nuraninya yang seolah-olah berbicara kepadanya.

"Mba percaya tidak dengan adanya suara-suara gaib, nyata ngga mba ya itu? Soalnya saya sering dengar, pas saya lagi sendirian, saya sering denger dan dari hati nurani saya, tapi biasanya kalau saya bawa ngaji suaranya tidak kedengaran lagi" (wawancara dengan HRS pada saat konseling dengan konselor)

Selain itu subjek HRS diketahui sering sekali melakukan hal-hal aneh, misalnya meminum air kencingnya sendiri, dan ia juga sering berkelahi dengan narapidana lain,

\footnotetext{
${ }^{14}$ Sarlito W. Sarwono, Psikologi Remaja Edisi Revisi (Jakarta: PT. Raja Grafindo Persada., 2011).
} 
menurut HRS hal tersebut, dikarenakan suara bisikan-bisikan itu yang menyuruhnya melakukan perbuatan itu.

Lain lagi dengan BSR, dari hasil wawancara dapat diketahui bahwa ia sering mengalami konflik batin seperti perasaan sedih, tertekan, merasa terbatasi, dan sangat ingin pulang ke rumah karena rindu dengan keluarga, serta perasaan-perasaan tidak mengenakkan lainnya yang muncul dari dalam dirinya. Kondisi psikologis dari aspek afektif menurut Frankl yang dialami oleh narapidana yaitu merasakan perasaan tidak bermakna (meaningless) yang ditandai dengan perasaan hampa, gersang, bosan, dan putus asa. ${ }^{15}$ Hasil wawancara kepada petugas lapas menyatakan aktivitas narapidana di Lembaga Pemasyarakatan Kelas II Karang Intan dalam unsur afeksi belum tersentuh secara optimal, karena tidak adanya psikolog dan kegiatan yang berhubungan dengan psikologis seperti aktivitas yang bisa meluapkan rasa sedih, cemas, dan perasaan kangen terhadap anggota keluarganya.

Selain pada aspek kognitif dan afektif, juga akan terlihat pada aspek psikomotroik atau aspek tingkah laku narapidana. Misalnya dapat termanisfestasikan dalam bentuk perilaku sulit tidur, tidak bersemangat dan kehilangan minat, bahkan keinginan untuk melukai sampai keinginan untuk mengakhiri hidup. Pada tindakan sulit tidur dari hasil wawancara termasuk paling sering dialami oleh para subjek penelitian baik HRS dan BSR dan juga narapidana yang lainnya. Bahkan lebih lanjut lagi menurut petugas lapas, tingginya tekanan psikologis yang dihadapi para narapidana kemudian menimbulkan perbuatan yang terlewat batas. Seperti terjadinya pertikaian sesama napi karena pengaruh salah persepsi dan juga emosional, serta percobaaan-percobaan bunuh diri atau melukai diri sendiri. Misalnya dengan meminum cairan pembersih kamar mandi, makan obat nyamuk bakar, maupun menyayat tangannya sendiri dengan barang apapun yang bisa digunakan. Hidup sebagai tahanan di dalam LP tentu bukanlah sesuatu yang menyenangkan, dengan keterbatasan ruang dan gerak akan sangat memungkinkan penghuninya untuk mengalami

\footnotetext{
${ }^{15}$ G.T Siahaan, "Hubungan Harga Diri dengan Makna Hidup pada Narapidana” (Skripsi, Universitas Sumatera Utara, 2008). 4.
} 
goncangan-goncangan psikologis, mulai dari stres ringan sampai pada tindakan yang paling mengerikan yaitu bunuh diri. ${ }^{16}$

Walaupun memang tidak semua narapidana mempunyai ide bunuh diri karena kondisi yang dihadapinya di Lapas, namun ada faktor-faktor tersebut yang mempermudah terbentuknya ide bunuh diri. Bunuh diri dapat diartikan sebagai 'indikator terberat' dan paling jelas hubungannya dengan kondisi psikologis seseorang. Jika seseorang sampai pada tindakan bunuh diri, adalah sangat mungkin bahwa indikator-indikator dari gangguan psikologis lain (kecemasan dan depresi) juga terdapat pada dirinya.

Seringkali kondisi psikologis yang dialami narapidana pada akhirnya juga menyebabkan keluhan-keluhan secara fisik yang makin 'parah'. Pada level fisiologis, menurut petugas lapas yang paling menonjol adalah keluhan-keluhan sakit kepala, fatigue, rasa lelah yang berlebihan, kurang bersemamgat dalam aktivitas keseharian atau melakukan aktivitas.

Sedangkan pada aspek sosial, narapidana menunjukkan perilaku cenderung menarik diri dari pergaulan antar sesama narapidana, sering duduk termenung dan menjadi penyendiri atau menutup diri, hal ini dikatakan BSR dari hasil wawancara karena menurutnya mereka yang beradadi dalam LP memiliki permasalahan yang sama. Berikut kutipan wawancara dari BSR :

"di dalam Lembaga Permasyarakatan ini tidak ada yang bisa diajak bicara, apalagi sesama narapidana, pastinya mereka memiliki masalah yang sama lagipula bercerita kepada mereka juga tidak akan ada solusi".

Penyebab dari kondisi psikologis mereka selain tentunya karena masa tahanan, selain itu juga di karenakan ada pengaruh keluarga, dari hasil wawancara kepada petugas kondisi psikologis mereka semakim parah dikarenakan banyak yang dicerai istrinya bahkan tidak dipedulikan lagi oleh keluarganya. Hal ini di dukung penelitian yang mengatakan bahwa penyebab terjadinya kondisi psikologis dapat berasal dari individu baik kondisi fisik (misalnya sakit) dan psikologis (misalnya konflik, prosesi persidangan, dan vonis hukum), maupun berasal dari sosial (misalnya interaksi anggota keluarga, tekanan pekerjaan dan

\footnotetext{
${ }^{16}$ Siti Thohurotul Ula, “Makna Hidup bagi Narapidana,” Jurnal Hisbah 11, no. No.1,Juni (2014): 16.
} 
ekonomi), serta dapat juga berasal dari komunitas atau lingkungan (misalnya sekolah, penjara dan kejadian-kejadian kompetitif).

\section{Kesimpulan}

Adapun kondisi psikologis yang dialami narapidana kasus narkotika dalam penelitian dapat dikelompokkan menjadi empat aspek, yaitu: 1) pada aspek kognitif dapat di gambarkan narapidana rentan mengalami disfungsi kognitif hal ini berkaitan dengan kemampuan persepsinya, yaitu daya tangkap dan sering kehilangan konsentrasi 2) Afektif yaitu kesedihan yang mendalam, kecurigaan dan kewaspadaan yang berlebihan, tertekan dan cemas 3) aspek sosial menunjukkan perilaku cenderung menarik diri dari pergaulan antar sesama narapidana, sering duduk termenung dan menjadi penyendiri atau menutup diri. 4) Psikomotorik di lihat dari tingkah laku maladaptif, dapat termanisfestasikan dalam bentuk perilaku sulit tidur, tidak bersemangat dan kehilangan minat, bahkan keinginan untuk melukai sampai keinginan untuk mengakhiri hidup.

\section{Saran}

Saran-saran yang dapat diberikan terutama bagi pihak Lembaga Pemasyarakatan sebaiknya memang perlu mengadakan program pendampingan psikologis bagi para narapidana narkotika khususnya, apalagi kalau narapidana yang masih tergantung perlu penyembuhan secara medis dan mental, proses detoksifikasi sangat penting artinya untuk proses kesembuhan secara menyeluruh. Selain itu melihat kondisi psikologis narapidana maka ada baiknya peran petugas di lapangan dapat dimaksimalkan untuk berinteraksi lebih dalam kepada narapidana supaya merasa lebih baik dan menerima serta memiliki tujuan hidup yang benar-benar mereka inginkan. 


\section{Kepustakaan}

Arsyah Sumardi. Jenis-Jenis Narkoba. Jakarta: Citizen Reporter, 2013.

Bonar Hutapea. “Terpenjara dan Bahagia? Psychological Well-Being Pada narapidana Ditinjau dari Karakteristik Kepribadian." Kepribadian.Proceeding Pesat (Psikologi, Ekonomi, Sastra, Arsitektur dan Sipil, 2011, 1858-2559.

C Morgan. "Developing Mental Health Service for Local Jails." Criminal Psychology: Science and Practice 5 (1981): 291-313.

"Data BNN menunjukkan peningkatan besar pengguna narkoba pasca eksekusi mati pengedar," 2016. http://www.batok.co/2016/04/19/data-bnn-menunjukkanpeningkatan-besar-pengguna-narkoba-pasca-eksekusi-mati-pengedar.

Deny Rahmawan. "Banyak Napi Narkoba Stres," 2016. http://malangvoice.com/banyaknapi-narkoba-stres/.

G.T Siahaan. "Hubungan Harga Diri dengan Makna Hidup pada Narapidana." Skripsi, Universitas Sumatera Utara, 2008.

Indiyah. "Hubungan antara religiusitas dan kepercayaan diri dengan kecemasan pada narapidana menjelang masa bebas." Universitas Gadjah Mada, 1997.

"Jumlah Pengguna Narkoba-di Kalimantan," 2016. http://portalindonesianews.com/posts/view/1626/tahun_2015_jumlah_penggunanark oba_di_indonesia_capai_5_juta_orang\#sthas.1sbBk1JA.dpuf.

Liwarti. "Hubungan antara pengalaman spritual dengan psychological Well-Being pada penghuni LembagaPermasyarakatan." Jurnal Sains dan Praktik Psikologi 1 (2013): 7788.

Purnianti, dan UNICEF. Analisa Situasi Sistem Peradilan Pidana Anak (Juvenile Justice System) di Indonesia. Jakarta: UNICEF, 2003.

R. Y Afrinisna. "Penyebab dan kondisi psikologis narapidana kasus narkoba pada remaja." Universitas Ahmad Dahlan, 2013.

S.A Kristianingsih. "Pemaknaan Pemenjaraan pada Narapidana Narkoba di Rumah Tahanan Salatiga." Humanitas Vol 6, no. No. 1 (2009): 1-15.

Sarlito W. Sarwono. Psikologi Remaja Edisi Revisi. Jakarta: PT. Raja Grafindo Persada., 2011.

Siti Thohurotul Ula. “Makna Hidup bagi Narapidana.” Jurnal Hisbah 11, no. No.1,Juni (2014): 16. 